\title{
Fastidiosipila sanguinis gen. nov., sp. nov., a new Gram-positive, coccus-shaped organism from human blood
}

\author{
Enevold Falsen, ${ }^{1}$ Matthew D. Collins, ${ }^{2}$ Christina Welinder-Olsson, ${ }^{1}$ \\ Yuli Song, ${ }^{3}$ Sydney M. Finegold ${ }^{3,4}$ and Paul A. Lawson ${ }^{2}$ \\ ${ }^{1}$ Culture Collection, Department of Clinical Bacteriology, University of Göteborg, Sweden \\ ${ }^{2}$ School of Food Biosciences, University of Reading, Reading, UK \\ ${ }^{3}$ Infectious Diseases Section, VA Medical Center, West Los Angeles, CA 90073, USA \\ ${ }^{4}$ Department of Medicine, UCLA School of Medicine, CA 90073, USA
}

Phenotypic and phylogenetic studies were performed on two strains of an unidentified Gram-positive, fastidious, non-spore-forming, coccus-shaped bacterium recovered from human blood. The organism was catalase-negative and grew under strictly anaerobic conditions and in the presence of 2 and $6 \% \mathrm{O}_{2}$. Comparative 16S rRNA gene sequencing demonstrated that the unidentified bacterium was, phylogenetically, far removed from peptostreptococci and related Gram-positive coccus-shaped organisms, but exhibited a phylogenetic association with Clostridium rRNA cluster III [as defined by Collins et al., Int J Syst Bacterio/ 44 (1994), 812-826]. Sequence divergence values of $15 \%$ or more were observed between the unidentified bacterium and all other recognized species within this and related rRNA clostridial clusters. Treeing analysis showed that the unknown bacterium formed a deep line branching at the periphery of rRNA cluster III and represents a hitherto unknown genus within this supra-generic grouping. On the basis of both phylogenetic and phenotypic evidence, it is proposed that the unknown bacterium from blood be classified in a new genus, Fastidiosipila gen. nov., as Fastidiosipila sanguinis sp. nov. The type strain of Fastidiosipila sanguinis is CCUG $47711^{\top}\left(=\operatorname{CIP} 108292^{\top}\right)$.

The anaerobic, Gram-positive cocci represent a taxonomically heterogeneous group of organisms. These organisms were at one time classified in a single family, 'Peptostreptococcaceae' (Rogosa, 1974), which included the genera Ruminococcus, Coprococcus, Sarcina, Peptococcus and Peptostreptococcus. During the past decade or so, knowledge of the phylogenetic inter-relationships of these organisms has been greatly clarified through the use of $16 \mathrm{~S}$ rRNA gene sequencing, and it is now known that the various genera of the anaerobic Gram-positive cocci are scattered throughout the Clostridium subphylum (Collins et al., 1994; Li et al., 1994; Murdoch et al., 1997). Phylogenetically, Peptostreptococcus anaerobius, the type species of the genus Peptostreptococcus, is a member of Clostridium rRNA group XI (see Collins et al., 1994, for group designations), whereas other peptostreptococci are found in Clostridium rRNA group XIII and now have been assigned to distinct genera (Anaerococcus, Finegoldia, Gallicola, Peptoniphilus;

Published online ahead of print on 29 October 2004 as DOI 10.1099/ ijs.0.63327-0.

The GenBank/EMBL/DDBJ accession number for the 16S rRNA gene sequence of strain CCUG $47711^{\top}$ is AJ575187.
Murdoch \& Shah, 1999; Ezaki et al., 2001). Sarcina ventriculi is a member of Clostridium rRNA group I, coprococci are related to the members of Clostridium rRNA group XVI, whereas ruminococci are located in two different rRNA lines (Collins et al., 1994; Rainey \& Janssen, 1995). In addition to these changes, a plethora of novel species of strictly anaerobic, Gram-positive cocci has been described in recent years (e.g. Murdoch et al., 1997; Ezaki et al., 1990; Li et al., 1992) and there are strong indications that much new diversity remains to be discovered, especially from human sources. During the course of a study of taxonomically problematic anaerobic organisms associated with human clinical specimens, we have characterized two isolates that represent a hitherto unknown genus of Grampositive cocci within Clostridium rRNA group III. On the basis of the phenotypic and phylogenetic findings presented here, we describe a new genus and novel species, Fastidiosipila sanguinis.

Strain CCUG $47711^{\mathrm{T}}$ was recovered from a blood specimen taken from an 84-year-old man in Karlstad, Sweden, whereas strain CCUG 47367 was isolated from the blood sample of an 87-year-old man from Göteborg, Sweden. The strains were cultivated on chocolate agar (Difco) and 
anaerobic blood agar (Oxoid) and incubated anaerobically at $37^{\circ} \mathrm{C}$ under a gas phase comprising $\mathrm{N}_{2} / \mathrm{H}_{2} / \mathrm{CO}_{2}$ (86: 7 : 7 , by vol.). Aerotolerance was determined by incubating the organism on Brucella agar plates (Difco) with and without $5 \%(\mathrm{v} / \mathrm{v})$ laked sheep blood in an atmosphere containing either $2 \%$ or $6 \% \mathrm{O}_{2}$, as described by Wexler et al. (1996). The strains were characterized biochemically by using a combination of conventional tests as described previously in the VPI Anaerobe Laboratory Manual (Holdeman et al., 1977) and the API Rapid ID 32S, API Rapid ID 32A and API ZYM systems according to the instructions of the manufacturer (bioMérieux). Fermentation tests were performed using pre-reduced, anaerobically sterilized peptone/ yeast/glucose broth (Anaerobe Systems) tubes. All biochemical tests were performed in duplicate. The $\mathrm{G}+\mathrm{C}$ content $(\mathrm{mol} \%)$ of the DNA was determined by HPLC according to Mesbah et al. (1989) except that the methanol content of the chromatographic buffer was decreased to $8 \%(\mathrm{v} / \mathrm{v})$ and the temperature was increased to $37^{\circ} \mathrm{C}$. The $16 \mathrm{~S}$ rRNA genes of the isolates were amplified by PCR using universal primers pA (positions 8-28, Escherichia coli numbering) and $\mathrm{pH}^{\star}$ (positions 1542-1522). The amplified products were purified by using a QIAquick PCR purification kit (Applied Biosystems) and directly sequenced using primers directed towards conserved positions of the rRNA gene, and using the dRhodamine terminator cycle sequencing kit (Applied Biosystems) and an automatic DNA sequencer (Applied Biosystems). The closest known relatives of the novel isolates were determined by performing database searches using the program FASTA (Pearson \& Lipman, 1985). These sequences and those of other known related strains were retrieved from GenBank and aligned with the newly determined sequence by using the program SEQtools (Rasmussen, 2002). The resulting multiple sequence alignment was corrected manually using the program GeneDoc (Nicholas et al., 1997). A phylogenetic tree was constructed according to the neighbour-joining method (Saitou \& Nei, 1987) with the programs SEQtools and TreeView (Page, 1996) and the stability of the groupings was estimated by bootstrap analysis (1000 replications) using the same programs.

The isolates originating from human blood specimens grew under strictly anaerobic conditions and also in the presence of 2 and $6 \% \mathrm{O}_{2}$. The organism formed small, coccus-shaped cells that stained Gram-positive. Spores were not observed. Colonies on chocolate agar and anaerobic blood agar were small, pinpoint and grey in colour. The organisms were non-haemolytic. Growth was poor in Fastidious Anaerobe Broth (Oxoid). The acid end-products formed in Fastidious Anaerobe Broth with meat granules were found to be acetic and butyric acids, in small amounts. Conventional biochemical methods revealed that the strains were catalase-, lecithinase- and urease-negative. The strains did not reduce nitrate and were indole-negative (both in the spot-indole test and in pre-reduced, anaerobically sterilized indolenitrate broth). Both strains failed to grow in peptone/yeast broth with fructose, glucose, inositol, lactose, maltose, mannose, mannitol, melibiose, raffinose, rhamnose, ribose, starch, sucrose or xylose. The unidentified isolates were relatively unreactive in the API Rapid ID $32 S$ tests. They hydrolysed hippurate and displayed $\alpha$-galactosidase, $\beta$ galactosidase, alanine phenylalanine proline arylamidase and $\beta$-mannosidase (weak reaction) activities. One isolate (CCUG $47711^{\mathrm{T}}$ ) was $\beta$-glucuronidase-positive. All other tests in the API Rapid ID 32S system gave negative results. The organisms were more reactive in the API Rapid ID 32A tests, displaying activity for $\alpha$-galactosidase, $\beta$-galactosidase, $\alpha$-glucosidase, $\beta$-glucosidase, $N$-acetyl- $\beta$-glucosaminidase, proline arylamidase and $\alpha$-fucosidase; reactions for serine arylamidase, histidine arylamidase, glycine arylamidase and tyrosine arylamidase were either weakly positive or negative. In the API ZYM tests, the strains gave positive reactions for $N$-acetyl- $\beta$-glucosaminidase, $\alpha$-galactosidase, $\alpha$-glucosidase and $\beta$-glucosidase, whereas reactions for acid phosphatase, ester lipase C8, phosphatase and phosphoamidase were either weakly positive or negative. Reactions for $\beta$-glucuronidase and esterase $\mathrm{C} 4$ were found to be variable. All other tests in the API ZYM gallery produced negative results. On the basis of their cellular morphology and overall biochemical reactions, the unidentified isolates did not appear to correspond to any currently described species of anaerobic cocci. The $\mathrm{G}+\mathrm{C}$ content of the DNA of strain CCUG $47711^{\mathrm{T}}$ was determined and found to be $32.9 \mathrm{~mol} \%$, which was consistent with the assignment of the isolates to the low- $\mathrm{G}+\mathrm{C}$ branch of the Gram-positive bacteria. To elucidate the phylogenetic position of the unidentified isolates, their almost-complete $16 \mathrm{~S}$ rRNA genes were amplified by PCR and then sequenced. The $16 \mathrm{~S}$ rRNA gene sequences were found to be identical to each other, and sequence database searches showed that the unidentified organisms displayed the highest sequence relatedness to members of the Clostridium subphylum (data not shown), consistent with their low $\mathrm{G}+\mathrm{C}$ content. On the basis of sequence similarities, the closest named relatives of the unidentified bacterium corresponded to species within Clostridium rRNA clusters III and IV (see Collins et al., 1994, for rRNA group designations). Treeing analysis showed that the unidentified bacterium clustered at the periphery of Clostridium rRNA cluster III, which includes Acetivibrio cellulolyticus, Bacteroides cellulosolvens and a variety of misclassified clostridial species (Fig. 1). Values for sequence divergence between the unidentified isolates and species of rRNA cluster III were invariably greater than $15 \%$ (data not shown).

From the findings presented, it is evident that the unidentified Gram-positive-staining, asporogenous, coccusshaped organism recovered from human blood represents a hitherto unknown line within the Clostridium subphylum of the Gram-positive bacteria (Collins et al., 1994). Phylogenetically, the unknown bacterium displays an affinity with rRNA cluster III, and is far removed from all other recognized genera of Gram-positive anaerobic cocci (viz. Anaerococcus, Coprococcus, Finegoldia, Gallicola, Peptoniphilus, Peptostreptococcus and Sarcina) which are found 


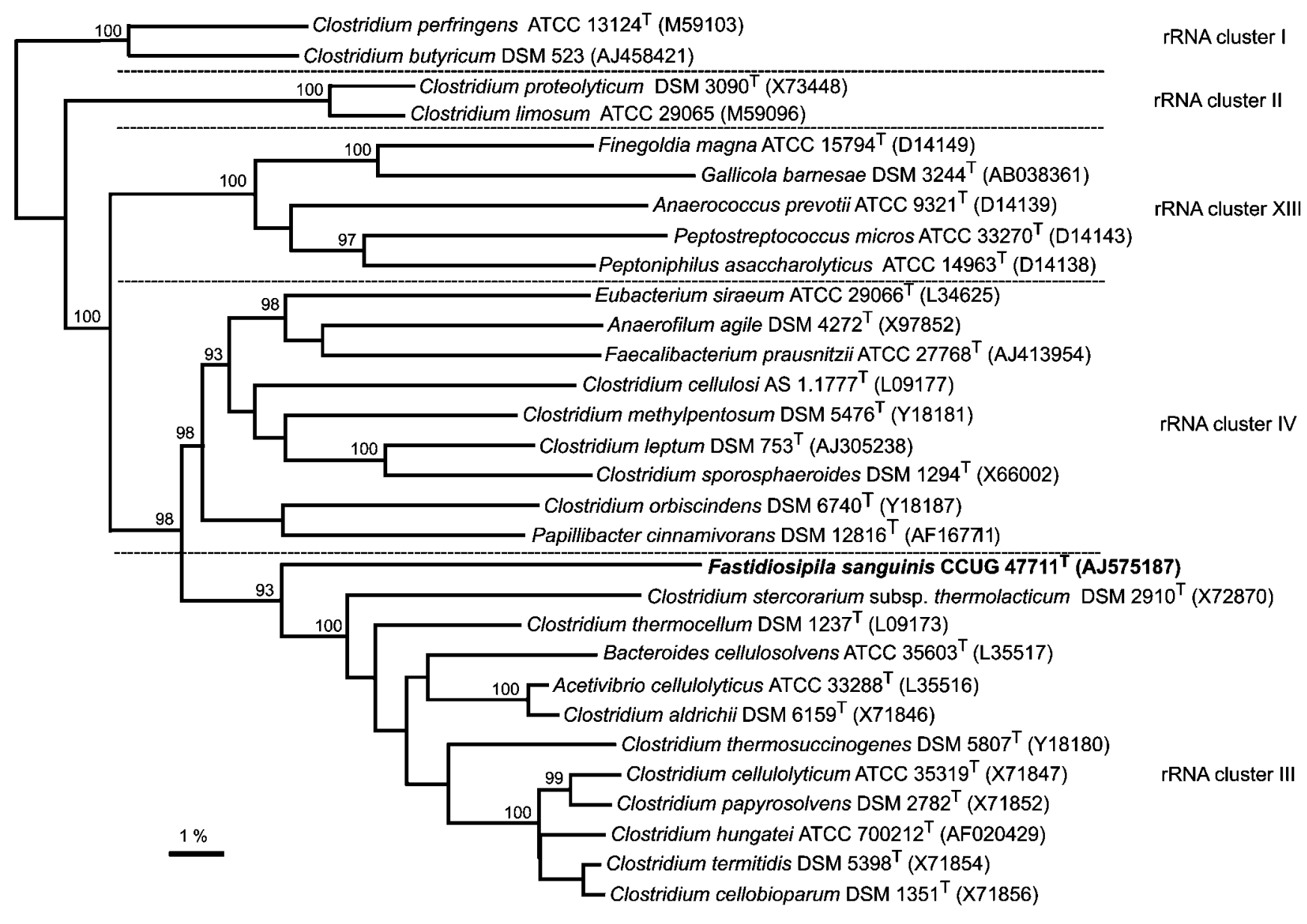

Fig. 1. Unrooted tree, based on $16 \mathrm{~S}$ rRNA gene sequences, showing the association between Fastidiosipila sanguinis gen. nov., sp. nov. and Clostridium rRNA cluster III and some other taxa. The tree, constructed using the neighbour-joining method, was based on a comparison of approximately $1330 \mathrm{nt}$. Bootstrap values, expressed as percentages of 1000 replications, are given at the branching points. Bar, $1 \%$ sequence divergence.

interspersed throughout a variety of phylogenetic groups (Collins et al., 1994; Murdoch \& Shah, 1999; Ezaki et al., 2001; Rainey \& Janssen, 1995). The association of the coccus-shaped organism with members of Clostridium rRNA clade III, however, was only loose, with the unknown bacterium branching deeply at the periphery of the cluster. Treeing analysis showed that the unknown bacterium did not have a close relationship with any individual member of Clostridium rRNA group III, although the branching at the base of the grouping was supported by a high bootstrap value. The distinctiveness of the unknown bacterium was also evident from divergence values of greater than $15 \%$ with members of rRNA cluster III and greater than $20 \%$ with other recognized Gram-positive, anaerobic cocci. Clostridium rRNA cluster III currently represents a small supra-generic grouping, embracing a diverse range of organisms including Acetivibrio cellulolyticus, the misclassified B. cellulosolvens and a variety of so-called clostridial species (viz. Clostridium cellobioparum, Clostridium cellulolyticum, Clostridium josui, Clostridium hungatei, Clostridium papyrosolvens, Clostridium stercorarium, Clostridium termitidis, Clostridium thermocellum and Clostridium thermosuccinogenes). In addition to high sequence divergence values and tree topology considerations, support for the separateness of the unknown bacterium from other organisms within Clostridium rRNA cluster III also comes from phenotypic considerations. In particular, the unidentified bacterium can be readily distinguished from all other taxa within this cluster by its small, coccoid cells and fastidious nature. Furthermore, the novel bacterium can be distinguished from Acetivibrio cellulolyticus and B. cellulosolvens by its Gram-positive staining reaction and the absence of cellulolytic activity (Murray et al., 1984; Patel et al., 1980). Similarly, the unknown organism differs from the misclassified clostridia within rRNA cluster III by not producing endospores and in terms of other phenotypic criteria (Table 1). Hence, given the phenotypic distinctiveness of the unknown coccus, together with its long rRNA line branching at the base of Clostridium rRNA cluster III, we consider that it merits inclusion in a new genus. We 
Table 1. Characteristics that are useful in differentiating Fastidiosipila sanguinis from other taxa in rRNA cluster III and some other related organisms

Taxa: 1, Fastidiosipila sanguinis; 2, Acetivibrio cellulolyticus; 3, Anaerofilum; 4, B. cellulosolvens; 5, Clostridium aldrichii; 6, C. cellobioparum; 7, C. cellulolyticum; 8, C. hungatei; 9, C. papyrosolvens; 10, C. stercorarium; 11, C. thermocellum; 12, C. thermosuccinogenes; 13, Faecalibacterium prausnitzii; 14, Papillibacter cinnaminivorans. Characteristics are scored as follows: +, positive; -, negative; D, straindependent; ND, not determined. Data for Fastidiosipila sanguinis are from the present study and data for the other taxa are from Cato et al. (1986), Defnoun et al. (2000), Duncan et al. (2002), Madden et al. (1982), Monserrate et al. (2001), Murray et al. (1984), Patel et al. (1980), Petitdemange et al. (1984), Yang et al. (1990) and Zellner et al. (1996).

\begin{tabular}{|c|c|c|c|c|c|c|c|c|c|c|c|c|c|c|}
\hline Characteristic & 1 & 2 & 3 & 4 & 5 & 6 & 7 & 8 & 9 & 10 & 11 & 12 & 13 & 14 \\
\hline Cellular morphology & Cocci & Rods & Rods & Rods & Rods & Rods & Rods & Rods & Rods & Rods & Rods & Rods & Rods & Rods \\
\hline Spores & - & - & - & - & + & + & + & + & + & $\mathrm{D}$ & + & + & - & - \\
\hline Gram stain & + & - & + & - & + & - & + & - & - & - & - & - & - & - \\
\hline Motility & - & + & $\mathrm{D}$ & - & + & + & + & + & + & $\mathrm{D}$ & - & + & - & - \\
\hline Flagella* & - & $\mathrm{M}$ & $\mathrm{P}$ & - & $\mathrm{PB}$ & $\mathrm{P}$ & $\mathrm{P}$ & SP & $\mathrm{P}$ & $\mathrm{P} / \mathrm{SL}$ & - & $\mathrm{P}$ & - & - \\
\hline $\begin{array}{l}\text { End-products of } \\
\text { metabolism } \dagger\end{array}$ & A, B & $\begin{array}{l}{ }^{\mathrm{a}} \mathrm{A}, \\
\mathrm{B}, \mathrm{P}\end{array}$ & $\begin{array}{c}\text { A, E, F, L, } \\
\text { 2,3-butanediol }\end{array}$ & $\begin{array}{l}{ }^{\mathrm{a}} \mathrm{A}, \\
\mathrm{E}, \mathrm{L}\end{array}$ & $\begin{array}{c}\text { A, B, P, } \\
\text { IB, IV, L, S }\end{array}$ & $\begin{array}{l}{ }^{\mathrm{b}} \mathrm{A}, \mathrm{E}, \\
\mathrm{L}, \mathrm{F}\end{array}$ & $\begin{array}{l}A, E \\
F, L\end{array}$ & $\begin{array}{l}{ }^{\mathrm{b}} \mathrm{A}, \mathrm{E} \\
\mathrm{L}, \mathrm{F}\end{array}$ & $\begin{array}{l}{ }^{\mathrm{b}} \mathrm{A}, \\
\mathrm{E}, \mathrm{L}\end{array}$ & $\begin{array}{c}\text { A, } \\
\text { L, E }\end{array}$ & $\begin{array}{l}{ }^{\mathrm{b}} \mathrm{A}, \\
\mathrm{E}, \mathrm{L}\end{array}$ & $\begin{array}{l}\text { A, E, } \\
\text { F, L, S }\end{array}$ & $\begin{array}{l}\text { B, L, } \\
\text { F, S }\end{array}$ & $\mathrm{ND}$ \\
\hline Cellulose degradation & - & + & - & + & + & + & + & + & + & + & + & - & - & - \\
\hline Growth at $60^{\circ} \mathrm{C}$ & - & - & - & - & - & - & - & - & - & + & + & + & - & - \\
\hline $\begin{array}{l}\text { DNA G + C content } \\
(\mathrm{mol} \%)\end{array}$ & 33 & 38 & $54-55$ & 43 & 40 & 28 & 41 & 40 & 30 & $39-43$ & $38-39$ & 36 & $47-57$ & 56 \\
\hline
\end{tabular}

*Abbreviations: M, monotrichous; P, peritrichous, PB, polar bundle; SL, single lateral; SP, subpolar.

$\dagger$ End-products: A, acetate; B, butyrate; E, ethanol; F, formate; IB, isobutyrate; IV, isovalerate; L, lactate; P, propionate; S, succinate ( ${ }^{\mathrm{a}}$ cellobiose fermentation, ${ }^{\mathrm{b}}$ cellulose fermentation).

therefore formally propose that the bacterium recovered from human blood be classified in a new genus and species, Fastidiosipila sanguinis gen. nov., sp. nov. Tests that are useful in distinguishing Fastidiosipila sanguinis from its nearest phylogenetic relatives and morphologically similar organisms are shown in Table 1 and Table 2, respectively.

\section{Description of Fastidiosipila gen. nov.}

Fastidiosipila (Fas.ti.di.o.si.pi'la. L. adj. fastidiosus fastidious; L. fem. n. pila ball; N.L. fem. n. Fastidiosipila a fastidious ball, because the organisms are difficult to grow).

Cells consist of Gram-positive-staining, non-spore-forming, small cocci. Growth occurs under strictly anaerobic conditions and also in the presence of 2 and $6 \% \mathrm{O}_{2}$. Catalasenegative. Carbohydrates are not fermented. Small amounts of acetic and butyric acids are detected in Fastidious Anaerobe Broth with meat granules. Lipase-, lecithinaseand urease-negative. Non-cellulolytic. Nitrate is not reduced. Indole-negative. The $\mathrm{G}+\mathrm{C}$ content of the DNA is $32.9 \mathrm{~mol} \%$. Fastidiosipila is a member of the Clostridium subphylum of the Gram-positive bacteria and is phylogenetically loosely associated with Clostridium rRNA group III.

The type species is Fastidiosipila sanguinis.

\section{Description of Fastidiosipila sanguinis sp. nov.}

Fastidiosipila sanguinis (san'gui.nis. L. gen. n. sanguinis of blood, referring to the source of the organism).
Cells consist of small cocci (approx. $0.5 \mu \mathrm{m}$ in diameter) that stain Gram-positive. After $48 \mathrm{~h}$ anaerobic incubation at $37^{\circ} \mathrm{C}$, colonies are small, pinpoint and grey in colour. Grows under anaerobic conditions and also in 2 and $6 \% \mathrm{O}_{2}$. Catalase-negative. Grows poorly on Fastidious Anaerobe Agar (Oxoid) and Fastidious Anaerobe Broth with meat granules. In the latter, small amounts of acetic and butyric acids are detected. Lecithinase, lipase and urease are not produced. Gelatin is not hydrolysed. In the API Rapid ID 32S system, activity is detected for $\alpha$-galactosidase, $\beta$-galactosidase, $\beta$-glucosidase, alanine phenylalanine proline arylamidase and $\beta$-mannosidase. No activity is detected for alkaline phosphatase, arginine dihydrolase, glycyl trypyophan arylamidase, pyroglutamic acid arylamidase or urease; $\beta$-glucuronidase activity may or may not be detected. Hippurate is hydrolysed and acetoin is not produced. In the API Rapid ID 32A system, positive reactions are obtained for $\alpha$-galactosidase, $\beta$-galactosidase, $\alpha$-glucosidase, $\beta$-glucosidase, $N$-acetyl- $\beta$-glucosaminidase, alanine arylamidase (weak), arginine arylamidase, proline arylamidase, leucine arylamidase (weak) and $\alpha$-fucosidase; reactions for serine arylamidase, histidine arylamidase, glycine arylamidase and tyrosine arylamidase are either weakly positive or negative. Activity is not detected for alkaline phosphatase, $\alpha$-arabinosidase, arginine dihydrolase, $\beta$-galactosidase-6-phosphate, glutamic acid decarboxylase, glutamyl glutamic acid arylamidase, $\beta$-glucuronidase, leucyl glycine arylamidase, phenyl alanine arylamidase, pyroglutamic acid arylamidase or urease. Indole is not produced and nitrate is not reduced. Sensitive to kanamycin 
Table 2. Characteristics that are useful in differentiating Fastidiosipila sanguinis from some other Gram-positive, coccusshaped taxa

Taxa: 1, Fastidiosipila sanguinis; 2, Anaerococcus prevotii; 3, Anaerococcus tetradius; 4, Anaerococcus lactolyticus; 5, Anaerococcus hydrogenalis; 6, Anaerococcus octavius; 7, Anaerococcus vaginalis; 8, Peptoniphilus asaccharolyticus; 9, Peptoniphilus lacrimalis; 10, Peptoniphilus harei; 11, Peptoniphilus ivorii; 12, Peptoniphilus indolicus; 13, Gallicola barnesae; 14, Finegoldia magna; 15, Micromonas micros; 16, Peptostreptococcus anaerobius; 17, Peptococcus niger. Characteristics are scored as follows: +, positive; -, negative; D, strain-dependent; W, weak. Data for Fastidiosipila sanguinis are from the present study; other data are from Ezaki et al. (2001).

\begin{tabular}{|c|c|c|c|c|c|c|c|c|c|c|c|c|c|c|c|c|c|}
\hline Characteristic & 1 & 2 & 3 & 4 & 5 & 6 & 7 & 8 & 9 & 10 & 11 & 12 & 13 & 14 & 15 & 16 & 17 \\
\hline $\begin{array}{l}\text { Major terminal volatile } \\
\text { fatty } \operatorname{acid}(s)^{*}\end{array}$ & A, B & B & B & B & B & B, C & B & $\mathrm{B}$ & B & B & B & B & A, B & A & A & IC, IV & $\mathrm{C}$ \\
\hline Indole & - & - & - & - & + & - & $\mathrm{D}$ & $\mathrm{D}$ & - & $\mathrm{D}$ & - & + & $\mathrm{W}$ & - & - & - & - \\
\hline Urease & - & $\mathrm{D}$ & + & + & $\mathrm{D}$ & - & - & - & - & - & - & - & - & - & - & - & - \\
\hline Glucose & - & $\mathrm{D}$ & $\mathrm{D}$ & + & + & + & + & - & - & - & - & - & - & - & - & + & - \\
\hline Lactose & - & - & - & + & + & - & - & - & - & - & - & - & - & - & - & - & - \\
\hline Raffinose & - & + & - & - & + & - & - & - & - & - & - & - & - & - & - & - & - \\
\hline Mannose & - & + & + & + & + & + & $\mathrm{D}$ & - & - & - & - & - & - & - & - & + & - \\
\hline \multicolumn{18}{|l|}{ Activity for: } \\
\hline Arginine arylamidase & $\mathrm{D}$ & + & + & + & - & - & + & + & + & + & - & + & - & + & + & - & - \\
\hline Proline arylamidase & + & - & - & - & - & + & - & - & - & - & + & - & - & - & + & + & - \\
\hline Phenylalanine arylamidase & - & - & $\mathrm{W}$ & - & - & - & - & - & + & - & - & + & - & - & - & - & - \\
\hline Leucine arylamidase & $\mathrm{D}$ & - & + & - & - & - & + & $\mathrm{D}$ & + & $\mathrm{D}$ & - & + & - & + & + & - & - \\
\hline $\begin{array}{l}\text { Pyroglutamic acid } \\
\text { arylamidase }\end{array}$ & - & + & $\mathrm{W}$ & - & - & $\mathrm{W}$ & - & - & - & - & - & - & - & + & + & - & - \\
\hline Histidine arylamidase & $\mathrm{D}$ & + & $\mathrm{W}$ & - & - & - & + & $\mathrm{W}$ & + & + & - & + & - & $\mathrm{D}$ & + & - & - \\
\hline DNA G $+\mathrm{C}$ content $(\mathrm{mol} \%)$ & 33 & $29-33$ & $30-32$ & $30-34$ & $30-34$ & $26-31$ & $30-34$ & $31-32$ & $30-34$ & 25 & 29 & $32-35$ & $32-34$ & $32-34$ & $28-30$ & $34-36$ & $50-51$ \\
\hline
\end{tabular}

${ }^{\star} \mathrm{A}$, acetate; B, butyrate; C, caproate; IC, isocaproate; IV, isovalerate.

$(1000 \mu \mathrm{g})$ and vancomycin $(5 \mu \mathrm{g})$, but resistant to colistin sulfate $(10 \mu \mathrm{g})$ and metronidazole $(5 \mu \mathrm{g})$ identification discs. The $\mathrm{G}+\mathrm{C}$ content of the DNA is $32.9 \mathrm{~mol} \%$. Isolated from human blood. Habitat is not known.

The type strain is CCUG $47711^{\mathrm{T}}\left(=\mathrm{CIP} 108292^{\mathrm{T}}\right)$.

\section{Acknowledgements}

We are grateful to Thomas Ahlqvist at the Public Health Laboratory Service in Karlstad, Sweden, and Chengxu Liu of the Wadsworth Anaerobic Bacteriology Laboratory, VA Medical Center, West Los Angeles, CA, USA.

\section{References}

Cato, E. P., George, W. L. \& Finegold, S. M. (1986). Genus Clostridium Prazmowski 1880, 23 ${ }^{\mathrm{AL}}$. In Bergey's Manual of Systematic Bacteriology, vol. 2, pp. 1141-1200. Edited by P. H. A. Sneath, N. S. Mair, M. E. Sharp \& J. G. Holt. Baltimore: Williams \& Wilkins.
Collins, M. D., Lawson, P. A., Willems, A., Cordoba, J. J., FernandezGarayzabal, J., Garcia, P., Cai, J., Hippe, H. \& Farrow, J. E. A. (1994). The phylogeny of the genus Clostridium: proposal of five new genera and eleven new species combinations. Int J Syst Bacteriol 44, 812-826.

Defnoun, S., Labat, M., Ambrosio, M., Garcia, J.-L. \& Patel, B. K. C. (2000). Papillibacter cinnamivorans gen. nov., sp. nov., a cinnamatetransforming bacterium from a shea cake digester. Int J Syst Evol Microbiol 50, 1221-1228.

Duncan, S. H., Hold, G. L., Harmsen, H. J. M., Steward, C. S. \& Flint, H. J. (2002). Growth requirements and fermentation products of Fusobacterium prausnitzii, and a proposal to reclassify it as Faecalibacterium prausnitzii gen. nov., comb. nov. Int J Syst Evol Microbiol 52, 2141-2146.

Ezaki, T., Liu, S.-L., Hashimoto, Y. \& Yabuuchi, E. (1990). Peptostreptococcus hydrogenalis sp. nov. from human fecal and vaginal flora. Int J Syst Bacteriol 40, 305-306.

Ezaki, T., Kawamura, Y., Li, N., Li, Z. Y., Zhao, L. \& Shu, S. (2001). Proposal of the genera Anaerococcus gen. nov., Peptoniphilus gen. nov. and Gallicola gen. nov. for members of the genus Peptostreptococcus. Int J Syst Evol Microbiol 51, 1521-1528. 
Holdeman, L. V., Cato, E. P. \& Moore, W. E. C. (1977). Anaerobe Laboratory Manual, 4th edn. Blacksburg, VA: Virginia Polytechnic Institute and State University.

Li, N., Hashimoto, Y., Adnan, S., Miura, H., Yamamoto, H. \& Ezaki, T. (1992). Three new species of the genus Peptostreptococcus isolated from humans: Peptostreptococcus vaginalis sp. nov., Peptostreptococcus lacrimalis sp. nov., and Peptostreptococcus lactolyticus sp. nov. Int $J$ Syst Bacteriol 42, 602-605.

Li, N., Hashimoto, Y. \& Ezaki, T. (1994). Determination of $16 \mathrm{~S}$ ribosomal RNA sequences of all members of the genus Peptostreptococcus and their phylogenetic position. FEMS Microbiol Lett 116, 1-5.

Madden, R. H., Bryder, M. J. \& Poole, N. J. (1982). Isolation and characterization of an anaerobic, cellulolytic bacterium, Clostridium papyrosolvens sp. nov. Int J Syst Bacteriol 32, 87-91.

Mesbah, M., Premachandran, U. \& Whitman, W. B. (1989). Precise measurement of the $\mathrm{G}+\mathrm{C}$ content of deoxyribonucleic acid by high-performance liquid chromatography. Int J Syst Bacteriol 39, 159-167.

Monserrate, E., Leschine, S. B. \& Canale-Parola, E. (2001). Clostridium hungatei sp. nov., a mesophilic, $\mathrm{N}_{2}$-fixing cellulolytic bacterium isolated from soil. Int J Syst Evol Microbiol 51, 123-132.

Murdoch, D. A. \& Shah, H. N. (1999). Reclassification of Peptostreptococcus magnus (Prevot 1933) Holdeman and Moore 1972 as Finegoldia magna comb. nov. and Peptostreptococcus micros (Prevot 1933) Smith 1957 as Micromonas micros comb. nov. Anaerobe 5, 555-559.

Murdoch, D. A., Collins, M. D., Willems, A., Hardie, J. M., Young, K. A. \& Magee, J. T. (1997). Description of three new species of the genus Peptostreptococcus from human clinical specimens: Peptostreptococcus harei sp. nov., Peptostreptococcus ivorii sp. nov., and Peptostreptococcus octavius sp. nov. Int J Syst Bacteriol 47, 781-787.

Murray, W. D., Sowden, L. C. \& Colvin, J. R. (1984). Bacteroides cellulosolvens sp. nov., a cellulolytic species from sewage sludge. Int J Syst Bacteriol 34, 185-187.

Nicholas, K. B., Nicholas, H. B., Jr \& Deerfield, D. W., II (1997). GeneDoc: analysis and visualization of genetic variation. EMBNEW News 4, 14.
Page, R. D. M. (1996). TreeView: an application to display phylogenetic trees on personal computers. Comput Appl Biosci 12, 357-358.

Patel, G. B., Khan, A. W., Agnew, B. J. \& Colvin, J. R. (1980). Isolation and characterization of an anaerobic, cellulolytic microorganism, Acetivibrio cellulolyticus gen. nov., sp. nov. Int J Syst Bacteriol 30, 179-185.

Pearson, W. R. \& Lipman, D. J. (1985). Rapid and sensitive protein similarity searches. Science 227, 1435-1441.

Petitdemange, E., Caillet, F., Giallo, J. \& Gaudin, C. (1984). Clostridium cellulolyticum sp. nov., a cellulolytic mesophilic species from decayed grass. Int J Syst Bacteriol 34, 155-159.

Rainey, F. A. \& Janssen, P. H. (1995). Phylogenetic analysis by $16 \mathrm{~S}$ ribosomal DNA sequence comparison reveals two unrelated groups of species within the genus Ruminococcus. FEMS Microbiol Lett 129, 69-73.

Rasmussen, S. W. (2002). SEQtools, a software package for analysis of nucleotide and protein sequences (http://www.seqtools.dk).

Rogosa, M. (1974). Family III. Peptostreptococcaceae Rogosa 1971. In Bergey's Manual of Determinative Bacteriology, 8th edn, pp. 517-528. Edited by R. E. Buchanan \& N. E. Gibbons. Baltimore: Williams \& Wilkins.

Saitou, N. \& Nei, M. (1987). The neighbor-joining method: a new method for reconstructing phylogenetic trees. Mol Biol Evol 4, 406-425.

Wexler, H. M., Reeves, D., Summanen, P. H., Molitoris, E., McTeague, M., Duncan, J., Wilson, K. H. \& Finegold, S. M. (1996). Sutterella wadsworthensis gen. nov., sp. nov., bile-resistant microaerophilic Campylobacter gracilis-like clinical isolates. Int J Syst Bacteriol 46, 252-258.

Yang, J. C., Chynoweth, D. P., Williams, D. S. \& Li, A. (1990). Clostridium aldrichii sp. nov., a cellulolytic mesophile inhabiting a wood-fermenting anaerobic digester. Int J Syst Bacteriol 40, 268-272.

Zellner, G., Stackebrandt, E., Nagel, D., Messner, P., Weiss, N. \& Winter, J. (1996). Anaerofilum pentosovorans gen. nov., sp. nov., and Anaerofilum agile sp. nov., two new, strictly anaerobic, mesophilic, acidogenic bacteria from anaerobic bioreactors. Int J Syst Bacteriol 46, 871-875. 